\title{
Transmembrane Fluoride Transport: Direct Measurement and Selectivity Studies
}

\author{
Harriet J. Clarke, ${ }^{\dagger}$ Ethan N. W. Howe, ${ }^{\dagger+}$ Xin Wu, ${ }^{\dagger,}$ Fabian Sommer, ${ }^{\S}$ Masafumi Yano, ${ }^{\dagger}$
}

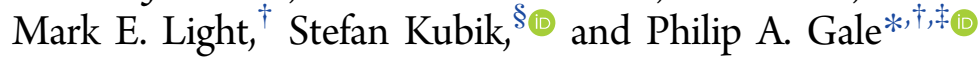

${ }^{\dagger}$ Chemistry, University of Southampton, Southampton SO17 1BJ, U.K.

${ }^{\S}$ Department of Chemistry-Organic Chemistry, Kaiserslautern University of Technology, Erwin-Schrödinger-Straße, 67663 Kaiserslautern, Germany

\section{Supporting Information}

ABSTRACT: Fluoride has been overlooked as a target in the development of synthetic anion transporters despite natural fluoride transport channels being recently discovered. In this paper we report the direct measurement of fluoride transport across lipid bilayers facilitated by a series of strapped calix[4]pyrroles and show that these compounds facilitate transport via an electrogenic mechanism (determined using valinomycin and monensin coupled transport assays and an additional osmotic response assay). An HPTS transport assay was used to quantify this electrogenic process and assess the interference of naturally occurring fatty acids with the transport process and $\mathrm{Cl}^{-}$over $\mathrm{H}^{+} / \mathrm{OH}^{-}$transport selectivity.

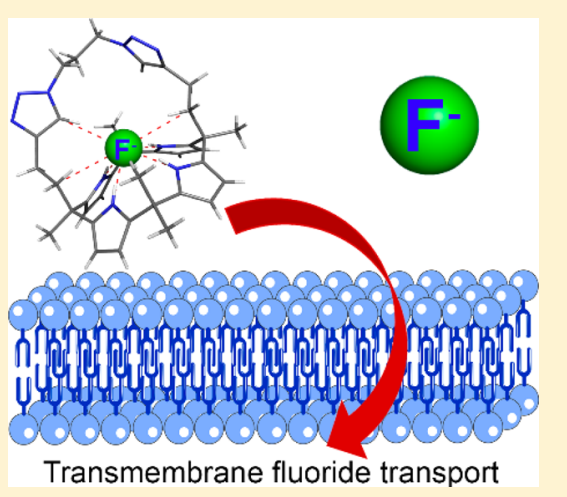

\section{INTRODUCTION}

Transmembrane ion transport facilitated by protein channels is essential in maintaining ion homeostasis. ${ }^{1}$ In the past decade, the development of synthetic anion transporters has attracted much attention, with a variety of small molecules being developed to facilitate the transport of biologically relevant anions such as chloride, ${ }^{2-12}$ bicarbonate, ${ }^{13-16}$ and sulfate. ${ }^{17}$ These compounds may find future application in the treatment of diseases caused by faulty ion channels, such as cystic fibrosis. ${ }^{1}$

Fluoride is used as an additive in water and oral hygiene products $^{18}$ and is found at levels of $10-100 \mu \mathrm{M}$ in the aqueous environment. ${ }^{19}$ Exposure to high levels of fluoride (above $1.5 \mathrm{mg} / \mathrm{L}^{20,21}$ ) can be detrimental to health, leading to fluorosis, which affects teeth and bones. ${ }^{22}$ To the best of our knowledge, no synthetic compound has been shown to facilitate fluoride transport across lipid bilayers. Fluoride is small, hard, and basic, with a higher hydration energy ${ }^{23}$ than chloride and bicarbonate, making fluoride complexation in water a challenging problem. In organic environments, deprotonation of anion receptors by fluoride, ${ }^{24-30}$ driven by the formation of bifluoride, can be a competing process to fluoride complexation. The use of Lewis acidic metal centers by Gabbai and co-workers in fluoride sensors has allowed fluoride detection in water below the maximum contaminant level (4 ppm) set by the Environment Protection Agency. ${ }^{31-33}$ Additionally, some Lewis acid-based compounds have been found to act as fluoride anionophores across artificial PVC-DOS membranes within the field of ionselective electrodes (ISEs), ${ }^{34}$ and fluoride sensing using boronic acid derivatives has been shown to be a successful strategy by
Shinkai, James, and others. ${ }^{35-37}$ In early work by Sessler and coworkers, fluoride transport through a liquid membrane system was facilitated by a protonated sapphyrin within a U-tube. ${ }^{38}$ The transmembrane exchange of fluoride facilitated by the protein capnophorin in red blood cells has also been investigated utilizing ${ }^{19} \mathrm{~F}$ NMR techniques. ${ }^{39}$ Other interesting work by Matile ${ }^{40}$ and Berezin ${ }^{41}$ has shown promising indirect results for fluoride as a potential target for lipid bilayer transport and provides a strong precedent that this transport is achievable.

Over the past 4 years, seminal work by Miller et al. has revealed the existence of two naturally occurring, phylogenetically unrelated families of $\mathrm{F}^{-}$exporter anion channels, $\mathrm{CLC}^{\mathrm{F}} \mathrm{F}^{-} / \mathrm{H}^{+}$antiporters, ${ }^{19,42-44}$ and small membrane channel "Fluc" proteins, ${ }^{45-48}$ the former found solely in bacterial cells, while the Fluc proteins are widespread among unicellular organisms as well as eukaryotes. These channels possess strong selectivity for $\mathrm{F}^{-}$over $\mathrm{Cl}^{-}$, and crystal structures of a Fluc channel from Bordetella pertussis reveal a surprising "doublebarreled" channel architecture in which selectivity is achieved by the small bore of the channel. ${ }^{48}$

These channels reduce bacterial fluoride toxicity, which occurs due to the weak acid accumulation effect, ${ }^{47}$ by exporting fluoride to maintain the cytoplasmic fluoride concentration below enzyme inhibitory levels.

We therefore decided to investigate whether it was possible to facilitate the transport of fluoride through lipid bilayers using

Received: October 17, 2016

Published: December 7, 2016 
small-molecule anion carriers and determine whether such transport could be achieved selectively over chloride transport. Herein we report the first instance of directly measured smallmolecule transmembrane fluoride transport with a series of strapped calix[4]pyrroles $2-4 .^{49}$ We have recently found that anion transporters can bind and facilitate the flip-flop of fatty acids across lipid bilayer membranes. ${ }^{50}$ We therefore also decided to investigate the interaction of these compounds both with acetate in solution and with fatty acids in lipid bilayers.

\section{RESULTS AND DISCUSSION}

We investigated whether strapped calix[4]pyrroles could be used to mediate fluoride transport. Calix[4] pyrroles are less acidic than the urea and thiourea transporter motifs that our group, and others, have recently explored and are therefore less likely to be deprotonated within the lipid bilayer. ${ }^{23}$ Calix[4]pyrroles 1-4 (Figure 1) were synthesized following literature procedures, ${ }^{49}$ and their $\mathrm{F}^{-}$binding affinity was<smiles>Cc1ccc(C(C)(C)c2ccc(C(C)(C)c3ccc(C(C)(C)c4ccc(C(C)(C)C)[nH]4)[nH]3)[nH]2)o1</smiles>

1

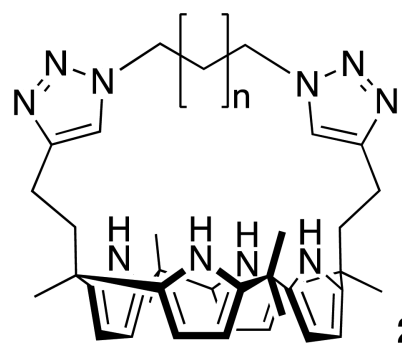

$2 n=1$ $3 n=2$ $4 n=3$
Figure 1. Structures of the calix[4]pyrroles 1-4 used in this study. evaluated using ${ }^{1} \mathrm{H}$ NMR titration methods and isothermal titration calorimetry (ITC). A variety of anion transport assays were employed to fully characterize the fluoride transport processes facilitated by $\mathbf{1 - 4} .^{51}$

Anion Binding Studies and Solid-State Analysis. Proton NMR titration studies in DMSO- $d_{6} / 0.5 \% \mathrm{H}_{2} \mathrm{O}$ with tetrabutylammonium fluoride (TBAF) and compounds 1-4 resulted in slow exchange of the fluoride complex and the free calix[4]pyrrole on the NMR time scale. A downfield shift of the pyrrole $\mathrm{NH}$ resonances and the triazole $\mathrm{CH}$ resonance and coupling of the $\mathrm{NH}$ resonance to the ${ }^{19} \mathrm{~F}$ nucleus of the fluoride anion were observed, which are usually indicative of strong hydrogen bonding. Slow exchange was observed previously with tetrabutylammonium chloride ( $\mathrm{TBACl}$ ) and compounds $\mathbf{2}-\mathbf{4}$. ${ }^{49}$ Slow exchange was also observed upon addition of tetrabutylammonium acetate with compounds $2-4$, and a stability constant of $6060 \mathrm{M}^{-1}$ was derived from global fitting analysis using bindfit ${ }^{52,53}$ with compound 1 in DMSO- $d_{6} / 0.5 \% \mathrm{H}_{2} \mathrm{O}$. An interesting splitting effect for the pyrrole $\mathrm{NH}$ was observed for the titration with 2 with acetate, suggesting two environments, which we attribute to the $\mathrm{OAc}^{-}$not binding symmetrically within the smaller cavity of compound 2 . NMR spectra and species ratio plots can be found in the Supporting Information. Quantification of the binding affinity was performed using ITC in acetonitrile. The results, summarized in Table 1 , show that compounds 1-4 exhibit exothermic complexation of both salts with slightly unfavorable entropic contributions for all, except 1 and 4, with tetraethylammonium fluoride. Receptors $1-4$ bind strongly to fluoride, with $K_{\mathrm{a}} \geq 10^{6} \mathrm{M}^{-1}$ with no indications of deprotonation, supporting their suitability for fluoride transport. This strong binding for $\mathbf{1 - 4}$ is similar to that seen for tetraethylammonium chloride binding, with previous literature

Table 1. Overview of the Association Constants and Thermodynamic State Functions for the 1:1 Complexation of Tetraethylammonium Salts with 1-4 As Measured in Acetonitrile by ITC at $303 \mathrm{~K}$

\begin{tabular}{|c|c|c|c|c|c|c|c|c|}
\hline \multirow[b]{2}{*}{ receptor } & \multicolumn{4}{|c|}{ fluoride } & \multicolumn{4}{|c|}{ acetate } \\
\hline & $K_{\mathrm{a}}\left(\mathrm{M}^{-1}\right)$ & $\Delta G\left(\mathrm{~kJ} \mathrm{~mol}{ }^{-1}\right)$ & $\Delta H\left(\mathrm{~kJ} \mathrm{~mol}{ }^{-1}\right)$ & $T \Delta S\left(\mathrm{~kJ} \mathrm{~mol}^{-1}\right)$ & $K_{\mathrm{a}}\left(\mathrm{M}^{-1}\right)$ & $\Delta G\left(\mathrm{~kJ} \mathrm{~mol}{ }^{-1}\right)$ & $\Delta H\left(\mathrm{~kJ} \mathrm{~mol}^{-1}\right)$ & $T \Delta S\left(\mathrm{~kJ} \mathrm{~mol}{ }^{-1}\right)$ \\
\hline 1 & $3.5 \times 10^{6}$ & -38.0 & -30.1 & 7.9 & $5.2 \times 10^{5}$ & -33.2 & -45.3 & -12.1 \\
\hline 2 & $1.3 \times 10^{6}$ & -35.5 & -44.5 & -9.0 & $1.3 \times 10^{5}$ & -29.7 & -41.4 & -11.7 \\
\hline 3 & $1.1 \times 10^{7}$ & -40.8 & -44.6 & -3.8 & $1.7 \times 10^{6}$ & -36.3 & -51.1 & -14.8 \\
\hline 4 & $1.9 \times 10^{7}$ & -42.2 & -34.5 & 7.7 & $1.2 \times 10^{6}$ & -35.4 & -42.7 & -7.3 \\
\hline
\end{tabular}
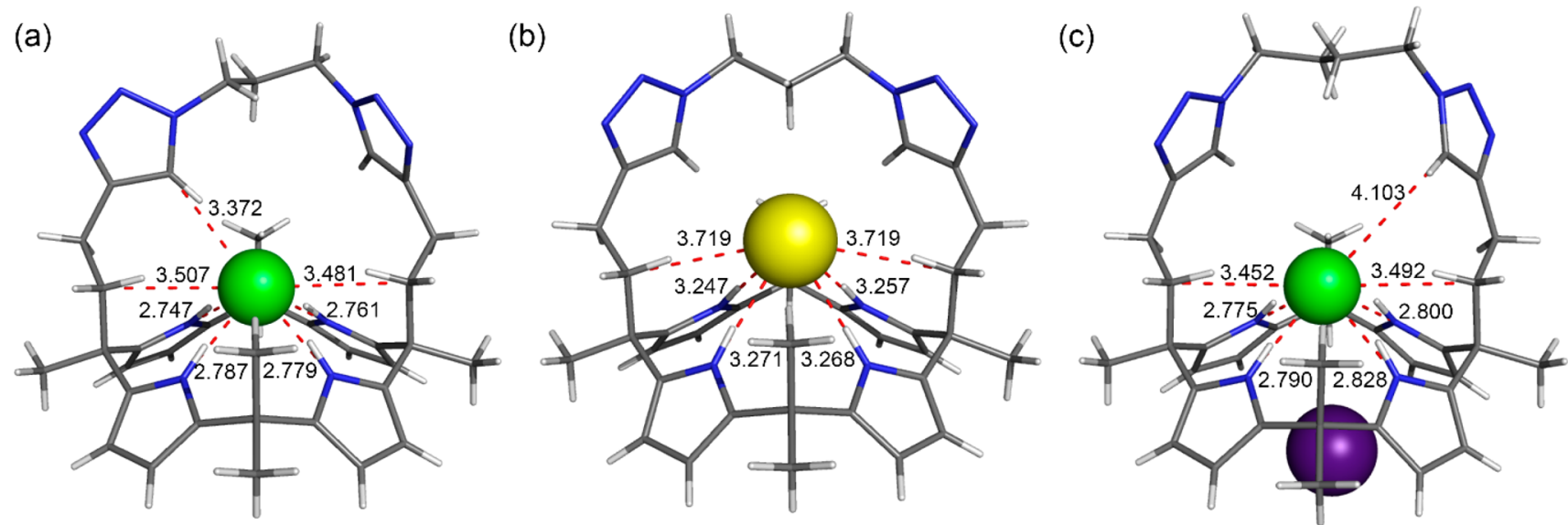

Figure 2. (a) Single-crystal X-ray structure of 2.TBAF complex (TBA not shown for clarity). (b) Single-crystal X-ray structure of 2.TBACl complex (TBA not shown for clarity). (c) Single-crystal X-ray structure of 3.CsF complex (ethanol solvent not shown for clarity). N $\cdots \mathrm{F}, \mathrm{N} \cdots \mathrm{Cl}, \mathrm{C} \cdots \mathrm{F}$, and $\mathrm{C} \cdots \mathrm{Cl}$ distances for all structures are displayed as red dashed lines, with measurements $(\AA)$ in black. Full crystallographic data can be found in the Supporting Information. 

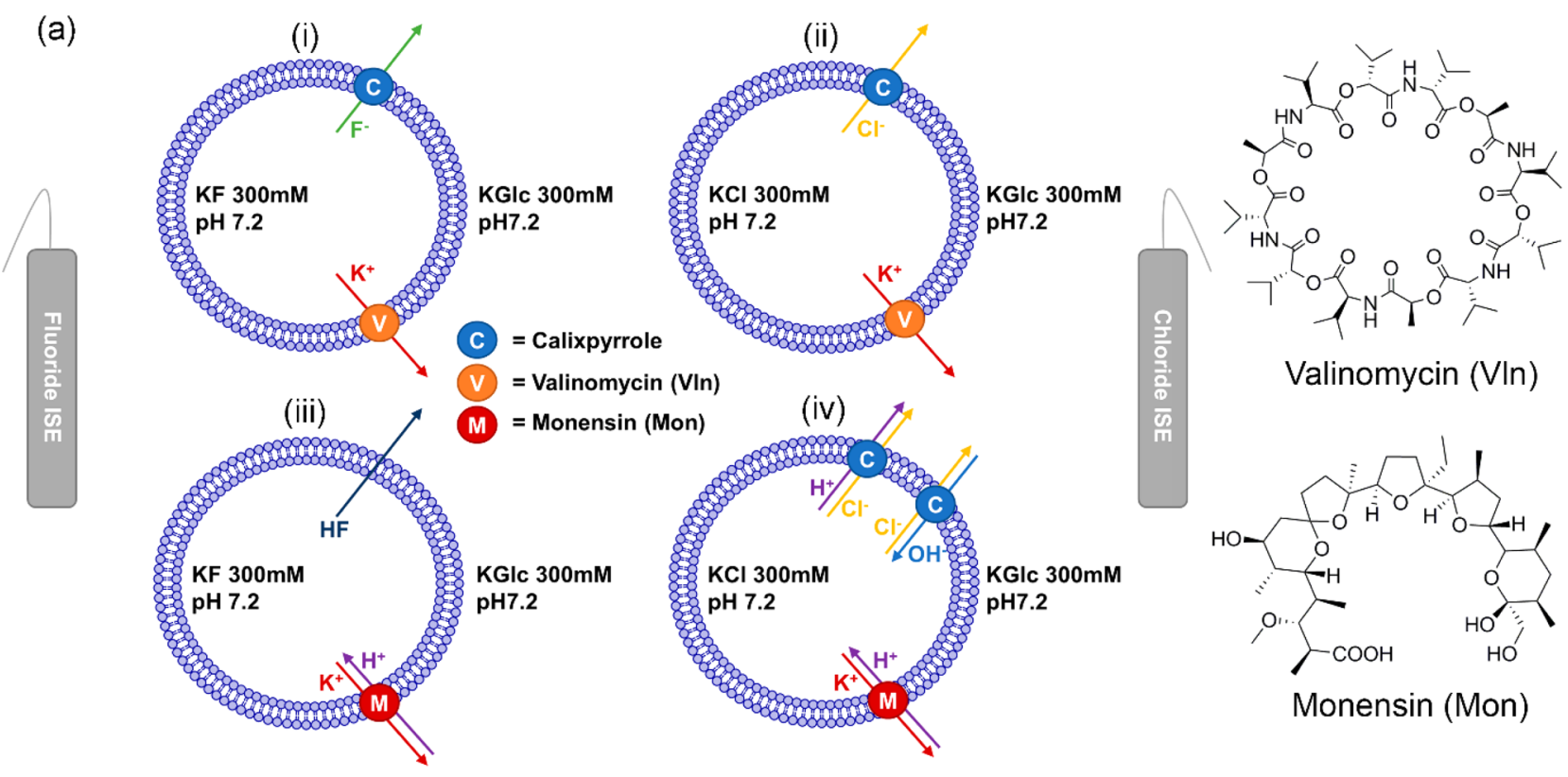

(b)

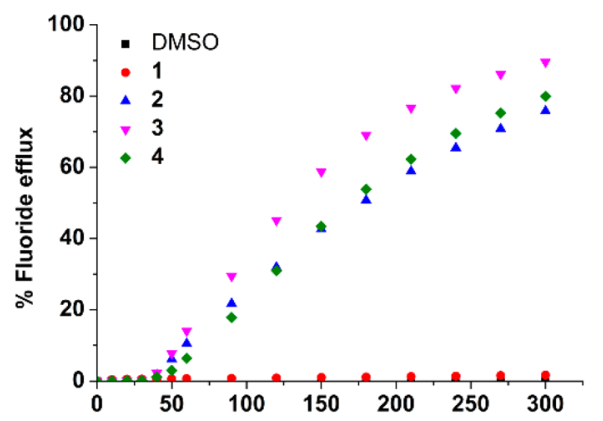

(d)

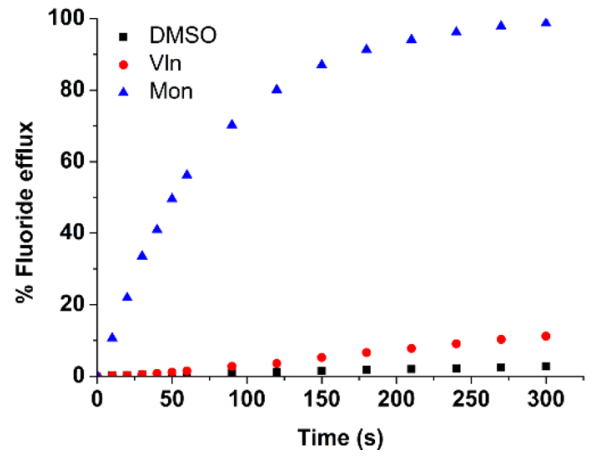

(c)

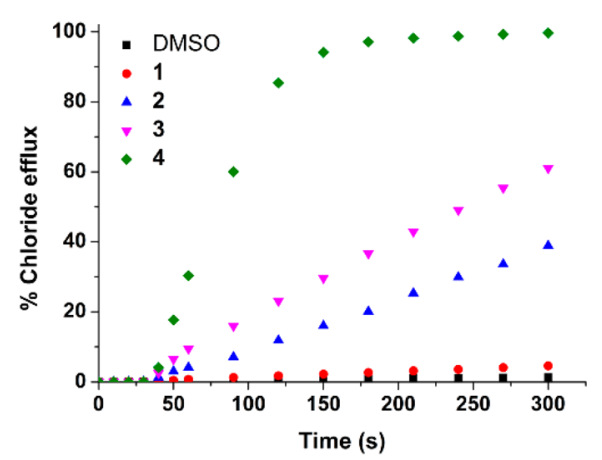

(e)

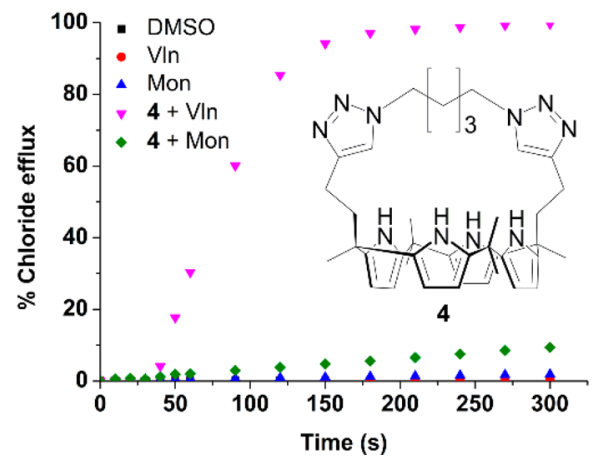

Figure 3. (a) Summary of the cationophore-coupled fluoride and chloride efflux ISE assays, including the structures of valinomycin and monensin. All ISE assays were performed with POPC LUVs $(200 \mathrm{~nm})$ loaded with $\mathrm{KF}$ or $\mathrm{KCl}(300 \mathrm{mM})$ and suspended in $\mathrm{KGlc}(300 \mathrm{mM})$ at pH 7.2 , and the anion efflux was monitored using a fluoride- or chloride-selective electrode. (i) Schematic showing net KF efflux from two electrogenic processes, $\mathrm{K}^{+}$transport and $\mathrm{F}^{-}$transport, facilitated by valinomycin $(1.0 \mu \mathrm{M}, 0.1 \mathrm{~mol} \%)$ and the calixpyrrole $(20 \mu \mathrm{M}, 2.0 \mathrm{~mol} \%)$, respectively. (ii) Schematic showing net $\mathrm{KCl}$ efflux from two electrogenic processes, $\mathrm{K}^{+}$transport and $\mathrm{Cl}^{-}$transport, facilitated by valinomycin $(1.0 \mu \mathrm{M}, 0.1 \mathrm{~mol} \%)$ and the calixpyrrole $(20 \mu \mathrm{M}, 2.0 \mathrm{~mol} \%)$, respectively. (iii) Schematic showing $\mathrm{KF}$ efflux caused by simple diffusion of $\mathrm{HF}$ coupled with $\mathrm{K}^{+} / \mathrm{H}^{+}$antiport facilitated by monensin $(1.0 \mu \mathrm{M}, 0.1 \mathrm{~mol} \%)$. (iv) Schematic showing formal $\mathrm{KCl}$ efflux from two electroneutral processes, $\mathrm{K}^{+} / \mathrm{H}^{+}$antiport and $\mathrm{H}^{+} / \mathrm{Cl}^{-}$symport $\left(\mathrm{OH}^{-} / \mathrm{Cl}^{-}\right.$antiport $)$, by monensin $(1.0 \mu \mathrm{M}, 0.1 \mathrm{~mol} \%)$ and the calixpyrrole $(20 \mu \mathrm{M}, 2.0 \mathrm{~mol} \%)$, respectively. (b) Fluoride efflux observed in the assay (a)-(i) facilitated by 1-4. (c) Chloride efflux observed in the assay (a)-(ii) facilitated by 1-4. (d) Fluoride efflux observed in the assay (a)-(iii) caused by the $\mathrm{K}^{+} / \mathrm{H}^{+}$antiport facilitated by monensin. (e) Chloride efflux observed in the assay (a)-(iv) facilitated by 4 in the presence of valinomycin and monensin.

reporting a $K_{\mathrm{a}}$ range of $10^{5}-10^{6} \mathrm{M}^{-1}$ in acetonitrile. ${ }^{49,54}$ Acetate binding was slightly weaker, with a $K_{\mathrm{a}}$ range of $10^{5}-10^{6} \mathrm{M}^{-1}$ (Table 1). As expected, acetate binding was stronger for 1, 3, and 4 compared to 2 , which may be due to the short strap constricting the binding cavity size. ITC binding isotherms can be found in the Supporting Information.
Solid-state structures of 2 complexed with $\mathrm{F}^{-}$and $\mathrm{Cl}^{-}$ (Figure 2a,b) show the anion bound within the strapped cavity, with shorter $\mathrm{N} \cdots \mathrm{F}$ distances of $2.747(3)-2.787(3) \AA$ observed compared to $\mathrm{N} \cdots \mathrm{Cl}(3.247(2)-3.271(2) \AA)$ and an additional stabilizing effect from the triazole $\mathrm{CH}$ for 2 -TBAF. Hence, the fluoride appears to be bound more strongly, at least 
in the solid state. Figure $2 \mathrm{c}$ shows the crystal structure of the cesium fluoride complex of 3 , which is similar to the cesium chloride complex of the parent macrocycle $1,{ }^{55}$ with $\mathrm{N} \cdots \mathrm{F}$ distances of $2.775(3)-2.828(4) \AA$ and the cesium sitting in the calixpyrrole cup-shaped cavity formed by the pyrrole rings.

Anion Transport Studies. The fluoride transport activities of 1-4 were probed using the vesicle-based ISE assay shown in Figure $3 \mathrm{a}(\mathrm{i})$, which was adapted from the literature. ${ }^{44}$ Large unilamellar vesicles (LUVs, $200 \mathrm{~nm}$ ) composed of 1-palmitoyl2-oleoyl-sn-glycero-3-phosphocholine (POPC) were loaded with $\mathrm{KF}(300 \mathrm{mM})$ and suspended in potassium gluconate (KGlc, $300 \mathrm{mM}$ ). All solutions were buffered to $\mathrm{pH} 7.2$ with HEPES (10 mM). Transport was initiated by addition of valinomycin (Vln), followed by the anionophore $30 \mathrm{~s}$ later, and fluoride efflux was measured directly using a fluoride selective electrode. The driving force in this assay is the large fluoride gradient. In the absence of valinomycin and an anion transporter, fluoride efflux is minimal. Fluoride efflux can occur only in the presence of valinomycin, which allows for the dissipation of the membrane potential that would occur if the fluoride transport facilitated by an anion transporter occurred alone. ${ }^{42,51}$ The results for this assay are shown in Figure $3 \mathrm{~b}$. Compounds 2-4 were all found to function as fluoride transporters at $20 \mu \mathrm{M}, 2 \mathrm{~mol} \%$ (with respect to lipid concentration), with 3 being the most effective, while compound 1 showed no transport activity under these conditions. Following this encouraging result, the assay was repeated in the absence of Vln with POPC vesicles loaded with $\mathrm{MF}(\mathrm{M}=\mathrm{Na}, \mathrm{K}, \mathrm{Cs}, \mathrm{Rb})$ to assess the group 1 metal cation co-transport abilities of 1-4.

Previous studies have shown that calix[4]pyrroles have high affinity for cesium halides. Small halide ions have been shown to organize 1 into a cone conformation, providing an electronrich cup which binds the large charge-diffuse $\mathrm{Cs}^{+}$cation. ${ }^{55,56}$

Earlier research confirms that $\mathbf{1}$ can selectively co-transport the $\mathrm{CsCl}$ ion pairs across lipid bilayers, and addition of a variety of straps can both enhance the affinity of the receptor for chloride and encapsulate the anion binding site. This allows the transporter to facilitate chloride uniport and hence permits processes such as $\mathrm{Cl}^{-} / \mathrm{NO}_{3}{ }^{-}$antiport to occur in addition to cesium chloride co-transport. ${ }^{49,57}$ Under the conditions of the transport experiment, all the receptors function as CsF co-transporters (and not $\mathrm{NaF}, \mathrm{KF}, \mathrm{RbF}$ ), with compound 1 outperforming compounds $2-4$. These results can be found in the Supporting Information.

To establish the selectivity for $\mathrm{F}^{-}$over $\mathrm{Cl}^{-}$, a series of doseresponse experiments were performed using the Vln-coupled assay used previously. For chloride, the POPC vesicles were loaded with $\mathrm{KCl}(300 \mathrm{mM})$ and the efflux was measured using a chloride-selective electrode, as seen in Figure 3a(ii). Hill analyses ${ }^{58}$ were performed to give the effective concentration to achieve $50 \%$ anion efflux $\left(\mathrm{EC}_{50}\right)$ at $270 \mathrm{~s}$, and the results are shown in Table 2 . The fluoride selectivity factor, $S_{\mathrm{F}}$, calculated by taking the ratio of $\mathrm{EC}_{50}\left(\mathrm{Cl}^{-}\right) / \mathrm{EC}_{50}\left(\mathrm{~F}^{-}\right)$, shows a preference for fluoride transport $\left(S_{\mathrm{F}}>1.0\right)$ for the shorter strapped receptors 2 and 3 compared to 4 , which displayed marginal chloride selectivity. This was attributed to the larger size of the binding cavity in 4 . These results also lead us to suggest that 2-4 can function as electrogenic fluoride transporters due to their ability to couple to $\mathrm{K}^{+}$transport, facilitated by electrogenic valinomycin. There is a net transfer of charge across the membrane by valinomycin-enabled potassium transport, thus dissipating the membrane potential ${ }^{61}$ that is caused by fluoride transport by $2-4$ to give overall KF efflux. To confirm
Table 2. Transport Activity from the Fluoride and Chloride ISE Assays with Fluoride Selectivity Factors $\left(S_{\mathrm{F}}\right)$, from Hill Analyses

\begin{tabular}{cccc} 
& \multicolumn{2}{c}{$\mathrm{EC}_{50}, \mu \mathrm{M}(\mathrm{mol} \%)^{a}$} & \\
\cline { 2 - 3 } receptor & $\mathrm{F}^{-}$ & $\mathrm{Cl}^{-}$ & ${ }^{b}$ \\
1 & $-^{c}$ & $-{ }^{c}$ & $-{ }^{c}$ \\
2 & $13(1.3)$ & $24(2.4)$ & 1.8 \\
3 & $9(0.9)$ & $16(1.6)$ & 1.8 \\
4 & $12(1.2)$ & $5(0.5)$ & 0.4
\end{tabular}

${ }^{a} \mathrm{EC}_{50}$ at $270 \mathrm{~s}$ of receptor with respect to lipid. ${ }^{b}$ Fluoride selectivity determined from $\mathrm{EC}_{50}$ for chloride transport divided by $\mathrm{EC}_{50}$ for fluoride transport. $S_{\mathrm{F}}>1$ indicates fluoride selectivity. ${ }^{c}$ No transport ability in this assay; no Hill analysis results or selectivity factors.

this mechanism, coupling to monensin (Mon), an electroneutral cationophore, was investigated. Mon facilitates $\mathrm{K}^{+} / \mathrm{H}^{+}$antiport and causes no transfer of net charge, but dissipates a $\mathrm{pH}$ gradient. ${ }^{62}$ If a receptor could facilitate $\mathrm{H}^{+} / \mathrm{F}^{-}$co-transport (or $\mathrm{F}^{-} / \mathrm{OH}^{-}$antiport), it would couple to Mon, preventing the buildup of a $\mathrm{pH}$ gradient and once again giving overall $\mathrm{KF}$ efflux. However, due to the electroneutral nature of Mon, even in the absence of an anionophore, $\mathrm{F}^{-}$is permeabilized in the form of $\mathrm{HF}$, and $100 \%$ efflux is observed within the experimental time scale (Figure $3 a($ iii) and $d$ ). Mon coupled experiments were therefore performed using KCl-loaded vesicles (Figure 3a(iv)) and the results compared to the Vln-coupled $\mathrm{Cl}^{-}$assay. Compounds 2-4 show no response when coupled to Mon, as illustrated in Figure $3 \mathrm{e}$ for $\mathbf{4}$ (the data for the other compounds are shown in the Supporting Information). These results support the hypothesis that 2-4 function via an electrogenic transport mechanism. An osmotic response assay was performed to provide further evidence in support of the electrogenic transport mechanism, and to provide supporting evidence to rule out $\mathrm{H}^{+}$or $\mathrm{OH}^{-}$transport. Vln and 1-4-facilitated $\mathrm{KF}$ (300 mM) efflux was monitored from POPC vesicles suspended in KGlc $(300 \mathrm{mM})$. Due to the formation of an osmotic gradient, water efflux follows the KF efflux, causing vesicle shrinkage. This increases the amount of $90^{\circ}$ light scattering, which can be monitored. Receptors 2-4 showed an increase in light scattering and therefore a positive response for Vln-coupled KF efflux, which can be seen in Figure 4a. To rule out $\mathrm{H}^{+}$and $\mathrm{OH}^{-}$ transport, which could cause background HF transport, a control assay was performed with KOAc-loaded vesicles. The acetate ion alone is membrane impermeable (unless transported); however, protonation of acetate resulting from transport of $\mathrm{H}^{+}$or $\mathrm{OH}^{-}$, potentially facilitated by $\mathbf{2 - 4}$, may form membrane-permeable acetic acid. Figure $4 \mathrm{~b}$ shows the results for 3 and 4 . No permeabilization of acetate was seen for $1-3$, which is evidence in support of the absence of $\mathrm{H}^{+}$and $\mathrm{OH}^{-}$transport. Conversely, 4 shows a positive result for the acetate control assay, which was attributed to the larger strapped cavity allowing for acetate binding and transport, and not $\mathrm{H}^{+}$or $\mathrm{OH}^{-}$transport. This is supported by the strong affinity of this receptor for $\mathrm{OAc}^{-}$from the ITC results and the fact the transport mechanism cannot couple to monensin.

Additionally, we quantified the $\mathrm{Cl}^{-}>\mathrm{H}^{+} / \mathrm{OH}^{-}$selectivity of the strapped calixpyrroles using a modified NMDG-Cl assay, ${ }^{10,51}$ which involves the use of gramicidin D (Gra), a naturally occurring proton channel, and oleic acid (OA), a naturally occurring monounsaturated omega-9 fatty acid. POPC LUVs $(200 \mathrm{~nm})$ were loaded with 8-hydroxypyrene-1,3,6-trisulfonic acid (HPTS, a pH-sensitive dye, $1 \mathrm{mM}$ ) and $\mathrm{N}$-methyl-D-glucamine 
chloride (NMDG-Cl, $100 \mathrm{mM}$ ) and suspended in NMDG-Cl $(100 \mathrm{mM}) .{ }^{10}$ All solutions were buffered to $\mathrm{pH} 7.0$ with HEPES (10 $\mathrm{mM})$. The anionophore was added, followed by a base pulse (NMDG $5 \mathrm{mM}$ ) to generate a $\mathrm{pH}$ gradient, and the dissipation of this gradient by the anionophore was monitored by following the HPTS fluorescence ratio. This assay measures the receptor's

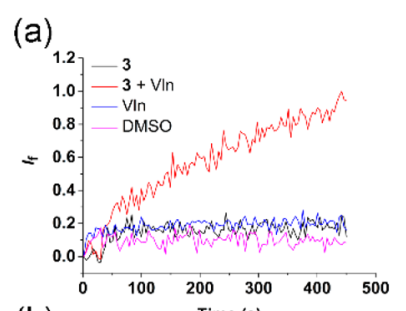

(b)
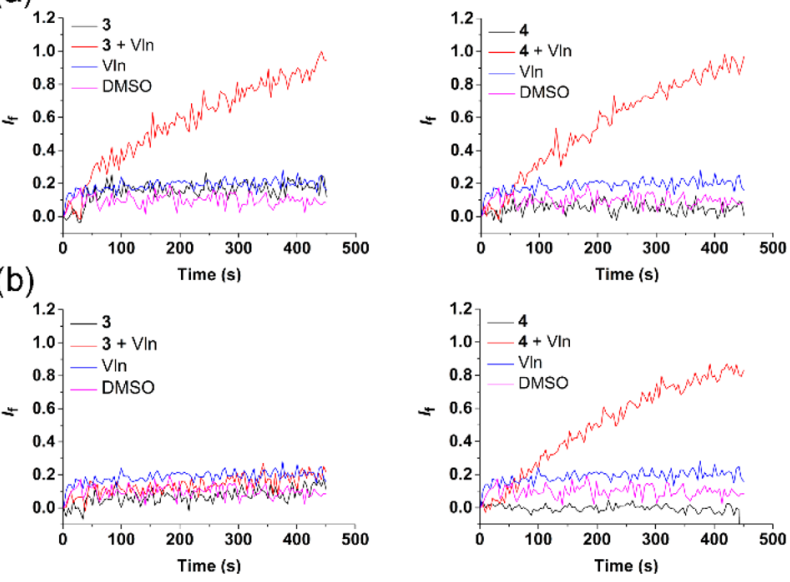

Figure 4. Overview of the osmotic assay results for 3 and 4. All assays were performed with POPC LUVs $(400 \mathrm{~nm})$ loaded with $\mathrm{KF}$ or KOAc $(300 \mathrm{mM})$ and suspended in KGlc $(300 \mathrm{mM})$ at $\mathrm{pH} 7.2$, and the anion efflux was measured indirectly by light scattering intensity. Top: (a) light scattering result caused by the efflux of fluoride facilitated by 3 and $\mathbf{4}$ and consequent dehydration of the vesicle. Bottom: (b) light scattering result caused by the efflux of acetate facilitated by 3 and 4 and consequent dehydration of the vesicle. electroneutral $\mathrm{H}^{+} / \mathrm{Cl}^{-}$co-transport $\left(\mathrm{Cl}^{-} / \mathrm{OH}^{-}\right.$antiport $)$ability. If the receptor functions as a selective electrogenic $\mathrm{Cl}^{-}$transporter, as found for 2-4, the $\mathrm{H}^{+} / \mathrm{OH}^{-}$transport will be the rate-limiting factor for transport. Addition of the proton channel Gra should accelerate the $\mathrm{H}^{+}$transport, removing this rate-limiting effect.

Quantification of the transport in both cases (with and without the proton channel) permits selectivity for chloride over proton or hydroxide transport to be calculated. Addition of oleic acid allows evaluation of the chloride selectivity of the receptors over the ability to contribute to the naturally occurring fatty acid proton transport pathway by assisting flip-flop of fatty acid anions described in Figure 5a,b. Figure 5a shows how a receptor capable of complexation to the deprotonated headgroup of a fatty acid can artificially enhance the natural proton shuttling seen with fatty acids in nature. ${ }^{59,60}$ Receptor masking of the charged headgroup accelerates movement of the charged form of the headgroup across the membrane. Figure $5 \mathrm{~b}$ (iii) shows this effect within the NMDG assay, with overall $\mathrm{H}^{+} / \mathrm{Cl}^{-}$symport being observed. Experimentally, this effect can artificially accelerate the $\mathrm{pH}$ gradient dissipation with the fatty acid flip-flop process, hence, the $\mathrm{Cl}^{-}>\mathrm{H}^{+} / \mathrm{OH}^{-}$selectivity will decrease in the presence of fatty acids within a membrane if the receptor has some affinity for the fatty acid headgroup. Since the presence of free (unesterified) fatty acids is ubiquitous in cellular membranes, this is important/undesirable in our ongoing effort in the development of $\mathrm{Cl}^{-}>\mathrm{H}^{+} / \mathrm{OH}^{-}$-selective synthetic anionophores for potential therapeutic application against cystic fibrosis. $^{50,51}$

Dose-response experiments and Hill analyses were performed in the absence and presence of gramicidin and oleic acid to gain $\mathrm{EC}_{50}$ values. The ratio of these $\mathrm{EC}_{50}$ values was (a)
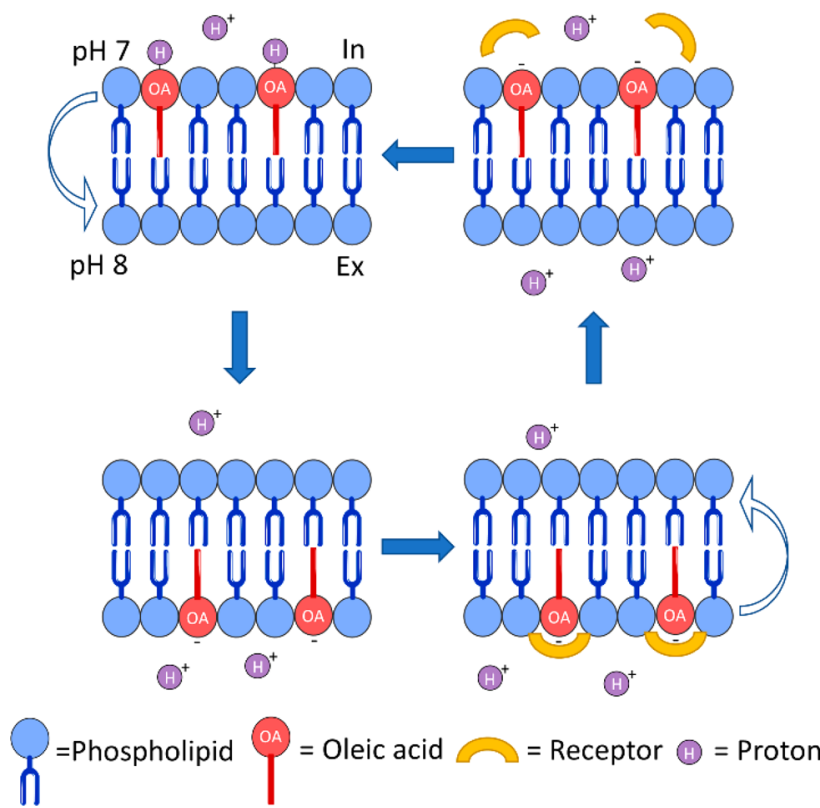

(b) (i)

(ii)

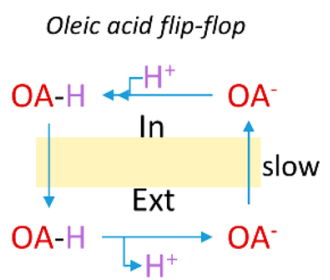

Receptor enhanced oleic acid flip-flop

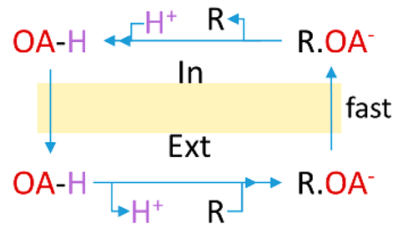

(iii)

Oleic acid head group/chloride antiport

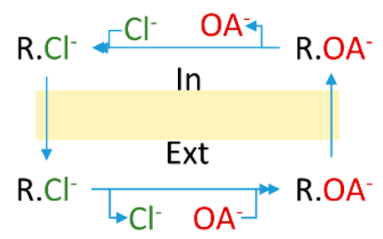

$\mathrm{OA}-\mathrm{H}=$ Oleic acid

$\mathrm{OA}^{-}=$Deprotonated oleic acid

Figure 5. Mechanism of fatty acid movement and proton transport across lipid bilayers, enhanced by an anion receptor and consequently increasing the HPTS response in the NMDG assay by accelerating the dissipation of the $\mathrm{pH}$ gradient. (a) Oleic acid molecules within the membrane bound to a proton undergo a flip-flop across the membrane from the $\mathrm{pH} 7$ interior to the $\mathrm{pH} 8$ exterior. These protons are deposited, causing a change in the $\mathrm{pH}$ gradient across the membrane. A receptor can then bind and transport the deprotonated acid headgroup back to the interior to complete the cycle, resulting in the dissipation of $\mathrm{pH}$ gradient. ${ }^{59,60}$ (b)-(i) Schematic to show the natural function of the oleic acid flip-flop with the slow, ratedetermining step. (ii) Schematic to show how a receptor can complex the deprotonated acid headgroup to accelerate the rate-determining step by masking the charge on the headgroup. (iii) Schematic to show this process in relation to the NMDG assay, causing $\mathrm{Cl}^{-} / \mathrm{OA}^{-}$antiport and overall $\mathrm{H}^{+} / \mathrm{Cl}^{-}$symport facilitated by a receptor and oleic acid, thus artificially increasing the $\mathrm{pH}$ dissipation rate. 
Table 3. Summary of $\mathrm{Cl}^{-}>\mathrm{H}^{+} / \mathrm{OH}^{-}$Selectivity for $1-4$

\begin{tabular}{|c|c|c|c|c|c|c|c|}
\hline receptor & $\mathrm{EC}_{50}, \mu \mathrm{M}\left(\mathrm{mol}^{h}\right)$ & $\mathrm{EC}_{50} \mathrm{Gra}, \mu \mathrm{M}\left(\mathrm{mol}^{h}\right)^{a}$ & $S_{\mathrm{G}}^{b}$ & $\mathrm{EC}_{50} \mathrm{OA}, \mu \mathrm{M}\left(\mathrm{mol}^{h}\right)^{c}$ & $F_{\mathrm{OA}}^{d}$ & $S_{\mathrm{OA} / \mathrm{G}}^{e}$ & $S_{\mathrm{OA} / \mathrm{G}}-S_{\mathrm{G}}^{f}$ \\
\hline 1 & $-^{g}$ & $-g$ & $-^{g}$ & $-g$ & $-^{g}$ & $-g$ & $-^{g}$ \\
\hline 2 & $10.9(10.9)$ & $0.6(0.6)$ & 18.2 & $11.2(11.2)$ & 1.0 & 18.7 & 0.5 \\
\hline 3 & $4.1(4.1)$ & $0.4(0.4)$ & 10.3 & $3.6(3.6)$ & 1.1 & 9.0 & -1.3 \\
\hline 4 & $2.7(2.7)$ & $0.2(0.2)$ & 13.5 & $1.6(1.6)$ & 1.7 & 8.0 & -5.5 \\
\hline
\end{tabular}

${ }^{a} \mathrm{EC}_{50}$ in the presence of gramicidin $\mathrm{D}$; this value shows the total $\mathrm{H}^{+} / \mathrm{Cl}^{-}$symport $\left(\mathrm{OH}^{-} / \mathrm{Cl}^{-}\right.$antiport $)$activity possible, with no rate-limiting $\mathrm{H}^{+} / \mathrm{OH}^{-}$transport. The Gra concentration added has been optimized at $0.1 \mu \mathrm{M}(0.1 \mathrm{~mol} \%)$ to prevent this having a limiting effect. ${ }^{b} \mathrm{Cl}^{-}>\mathrm{H}^{+} / \mathrm{OH}^{-}$ selectivity value $S_{\mathrm{G}}$ is calculated by dividing $\mathrm{EC}_{50}$ in the absence of Gra by the $\mathrm{EC}_{50} \mathrm{Gra} S_{\mathrm{G}}>1$ indicates $\mathrm{Cl}^{-}$selectivity. ${ }^{{ }^{c}} \mathrm{EC}_{50}$ in the presence of oleic acid $(2 \mu \mathrm{M}, 2 \mathrm{~mol} \%)$; this value helps to show the effect of the fatty acid on the selectivity results. ${ }^{d} \mathrm{Factor}$ of overall $\mathrm{H}^{+} / \mathrm{Cl}^{-}$symport enhancement in the presence of $\mathrm{OA}$, calculated by dividing $\mathrm{EC}_{50}$ in the absence of Gra or $\mathrm{OA}$ by $\mathrm{EC}_{50} \mathrm{OA} . F_{\mathrm{OA}}>1$ suggests that the receptor can assist the flip-flop of $\mathrm{OA}^{-}$, enhancing $\mathrm{pH}$ dissipation. ${ }^{e} \mathrm{Cl}^{-}>\mathrm{H}^{+} / \mathrm{OH}^{-}$selectivity value in the presence of oleic acid, calculated by dividing $\mathrm{EC}_{50} \mathrm{OA}$ by the $\mathrm{EC}_{50}$ Gra. $S_{\mathrm{OA} / \mathrm{G}}>1$ indicates $\mathrm{Cl}^{-}$selectivity. ${ }^{f} \mathrm{If} S_{\mathrm{OA} / \mathrm{G}}-S_{\mathrm{G}} \approx 0$, there is no selectivity loss in the presence of OA. ${ }^{g}$ No transport ability in this assay; no Hill analysis results or selectivity factors calculated. ${ }^{h}$ Concentration of receptor with respect to lipid.

used to quantify the chloride selectivity, giving selectivity factors $\left(S_{\mathrm{G}}\right.$ and $\left.S_{\mathrm{OA} / \mathrm{G}}\right)$ presented in Table 3. It is important to note that these selectivity factors are relative to the $\mathrm{Cl}^{-}$ concentration used within the assay. ${ }^{51}$ Receptors 2-4 show good selectivity for chloride along the series, with an $S_{\mathrm{G}}$ of 18.2, 10.3 , and 13.5 , respectively; 2 , the shortest strapped, smallest cavity receptor possessed the highest selectivity for chloride, which supports previous findings that a higher degree of anion encapsulation enforces a higher degree of anion desolvation and hence better selectivity for chloride transport. ${ }^{51}$ Figure 6 shows

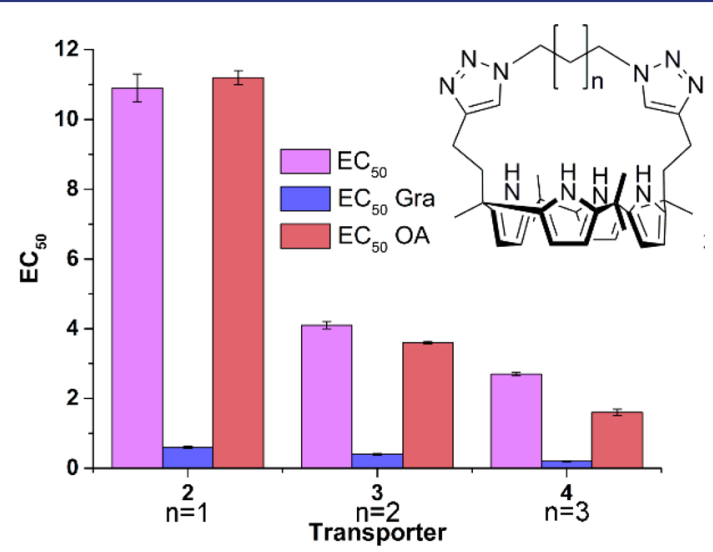

Figure 6. Bar chart of $\mathrm{EC}_{50}$ results for 2-4 from POPC LUVs (200 $\mathrm{nm})$ loaded with NMDG-Cl $(100 \mathrm{mM})$ and HPTS (1 mM) suspended in NMDG-Cl $(100 \mathrm{mM})$. The $\mathrm{H}^{+} / \mathrm{Cl}^{-}$symport (or $\mathrm{OH}^{-} / \mathrm{Cl}^{-}$antiport) dose-response of 2-4 was measured by monitoring the HPTS fluorescence ratio after the addition of a $5 \mathrm{mM}$ NMDG pulse (with an additional pulse of gramicidin D $(0.1 \mu \mathrm{M}$, $0.1 \mathrm{~mol} \%)$ or oleic acid $(2 \mu \mathrm{M}, 2 \mathrm{~mol} \%)$ as appropriate). The Hill equation was used to fit the dose-response curves for 2-4 alone, with gramicidin $\mathrm{D}$, and with oleic acid. Kinetic profiles, Hill plots, and the Hill equation can be found in the Supporting Information.

the $\mathrm{EC}_{50}$ values in a bar chart to help visualize this selectivity. In the presence of oleic acid, the effect of artificially enhanced $\mathrm{H}^{+} / \mathrm{Cl}^{-}$symport due to the fatty acid flip-flop side process is negligible in $\mathbf{2}$ and 3; however, there is a mild increase in the transport ability of $\mathbf{4}$ by a factor of 1.7 . This result correlates to the findings in the osmotic assay and ITC study that 4 is likely to bind and transport acetate, as it is more inclined to bind the oxoanionic oleic acid headgroup (Figure 5) to enhance its proton shuttle effect and therefore accelerate the dissipation of the $\mathrm{pH}$ gradient. ${ }^{63}$ This resulted in a loss of $\mathrm{Cl}^{-}>\mathrm{H}^{+} / \mathrm{OH}^{-}$ selectivity $\left(S_{\mathrm{OA} / \mathrm{G}}\right)$ for 4 by a difference of 5.5 ; while there is a small loss for 3 , the selectivity of the shortest strapped 2 was not compromised in the presence of fatty acid. These results reiterated the advantageous effect of encapsulation and enforced steric hindrance in the design of synthetic anion transporters for overall $\mathrm{Cl}^{-}>\mathrm{H}^{+} / \mathrm{OH}^{-}$selectivity.

\section{CONCLUSIONS}

Using a fluoride ion-selective electrode assay, we have shown the first example of a direct measurement of small synthetic molecule facilitated, transmembrane fluoride transport via an electrogenic anion transport mechanism, mimicking an important natural transport process that occurs in bacteria. The shorter strapped receptors $\mathbf{2}$ and $\mathbf{3}$ are moderately selective for fluoride over chloride in the Vln coupled assay. Additionally, we have quantified the $\mathrm{Cl}^{-}>\mathrm{H}^{+} / \mathrm{OH}^{-}$selectivity of $2-4$, finding them highly selective for $\mathrm{Cl}^{-}$over $\mathrm{H}^{+} / \mathrm{OH}^{-}$, which supports previous findings that encapsulation is the key to selectivity. ${ }^{51}$ We also evaluated how the presence of a naturally occurring fatty acid interferes with the receptor's transport mechanism and compromises the overall $\mathrm{Cl}^{-}>\mathrm{H}^{+} / \mathrm{OH}^{-}$selectivity, confirming the need for consideration of fatty acid affinity when designing transporters for physiological purposes. Remarkably, the shortest strapped calixpyrrole 2 not only demonstrated the best $\mathrm{Cl}^{-}>$ $\mathrm{H}^{+} / \mathrm{OH}^{-}$selectivity but also fully maintained the selectivity in the presence of fatty acid. These results illustrate the importance of encapsulation and point the way forward in the design of halide-selective transporters.

\section{ASSOCIATED CONTENT}

\section{S Supporting Information}

The Supporting Information is available free of charge on the ACS Publications website at DOI: 10.1021/jacs.6b10694.

Details of general procedures, NMR binding studies, ITC, single-crystal X-ray studies for 2 and 3, and all anion transport experimental details for all the vesiclebased assays used in this study (PDF)

Crystallographic data for 2 (CIF)

Crystallographic data for $2 \cdot \mathrm{TBACl}$ (CIF)

Crystallographic data for $2 \cdot \mathrm{TBAF}$ (CIF)

Crystallographic data for $3 \cdot \mathrm{CsF}$ (CIF)

\section{AUTHOR INFORMATION}

\section{Corresponding Author}

*philip.gale@sydney.edu.au

ORCID

Stefan Kubik: 0000-0003-0526-7014

Philip A. Gale: 0000-0001-9751-4910 


\section{Present Address}

${ }^{\ddagger}$ For E.N.W.H., X.W., and P.A.G.: School of Chemistry (F11), The University of Sydney, 2006 NSW, Australia

\section{Notes}

The authors declare no competing financial interest.

The data from this study have been made available at http://dx. doi.org/10.5258/SOTON/403025 to comply with the EPSRC open data policy.

\section{ACKNOWLEDGMENTS}

We thank the EPSRC for a studentship to H.J.C. (EP/ L0505067/1) and for access to the crystallographic facilities at the University of Southampton. P.A.G. thanks the Royal Society and the Wolfson Foundation for a Research Merit Award.

\section{REFERENCES}

(1) Ashcroft, F. M. Ion Channels and Disease Channelopathies; Academic Press: San Diego, 2000.

(2) Davis, J. T.; Okunola, O.; Quesada, R. Chem. Soc. Rev. 2010, 39, 3843-3862.

(3) Matile, S.; Vargas Jentzsch, A.; Montenegro, J.; Fin, A. Chem. Soc. Rev. 2011, 40, 2453-2474.

(4) Busschaert, N.; Gale, P. A. Angew. Chem., Int. Ed. 2013, 52, 1374-1382.

(5) Gale, P. A.; Pérez-Tomás, R.; Quesada, R. Acc. Chem. Res. 2013, 46, 2801-2813.

(6) Busschaert, N.; Caltagirone, C.; Van Rossom, W.; Gale, P. A. Chem. Rev. 2015, 115, 8038-8155.

(7) Valkenier, H.; Judd, L. W.; Li, H.; Hussain, S.; Sheppard, D. N.; Davis, A. P. J. Am. Chem. Soc. 2014, 136, 12507-12512.

(8) Hernández, P. I.; Moreno, D.; Javier, A. A.; Torroba, T.; PérezTomás, R.; Quesada, R. Chem. Commun. 2012, 48, 1556-1558.

(9) Gale, P. A.; Howe, E. N. W.; Wu, X. Chem. 2016, 1, 351-422.

(10) Dawson, R. E.; Hennig, A.; Weimann, D. P.; Emery, D.; Ravikumar, V.; Montenegro, J.; Takeuchi, T.; Gabutti, S.; Mayor, M.; Mareda, J.; Schalley, C. A.; Matile, S. Nat. Chem. 2010, 2, 533-538.

(11) Vargas Jentzsch, A.; Matile, S. J. Am. Chem. Soc. 2013, 135, 5302-5303.

(12) Benz, S.; Macchione, M.; Verolet, Q.; Mareda, J.; Sakai, N.; Matile, S. J. Am. Chem. Soc. 2016, 138, 9093-9096.

(13) Gale, P. A.; Tong, C. C.; Haynes, C. J. E.; Adeosun, O.; Gross, D. E.; Karnas, E.; Sedenberg, E. M.; Quesada, R.; Sessler, J. L. J. Am. Chem. Soc. 2010, 132, 3240-3241.

(14) Davis, J. T.; Gale, P. A.; Okunola, O. A.; Prados, P.; IglesiasSánchez, J. C.; Torroba, T.; Quesada, R. Nat. Chem. 2009, 1, 138-144.

(15) Andrews, N. J.; Haynes, C. J. E.; Light, M. E.; Moore, S. J.; Tong, C. C.; Davis, J. T.; Harrell, W. A., Jr.; Gale, P. A. Chem. Sci. 2011, 2, 256-260.

(16) Busschaert, N.; Gale, P. A.; Haynes, C. J. E.; Light, M. E.; Moore, S. J.; Tong, C. C.; Davis, J. T.; Harrell, W. A., Jr. Chem. Commun. 2010, 46, 6252-6254.

(17) Busschaert, N.; Karagiannidis, L. E.; Wenzel, M.; Haynes, C. J. E.; Wells, N. J.; Young, P. G.; Makuc, D.; Plavec, J.; Jolliffe, K. A.; Gale, P. A. Chem. Sci. 2014, 5, 1118-1127.

(18) Hamilton, I. R. J. Dent. Res. 1990, 69, 660-663.

(19) Stockbridge, R. B.; Lim, H.-H.; Otten, R.; Williams, C.; Shane, T.; Weinberg, Z.; Miller, C. Proc. Natl. Acad. Sci. U. S. A. 2012, 109, $15289-15294$

(20) Cao, S. R.; Li, Y. F. Proceedings of the XIX Conference of the International Society for Fluoride Research, Kyoto, 1992; $\mathrm{p} 38$.

(21) World Health Organisation. In Guidelines for drinking-water quality; IWA Publishing: London, 2006; pp 1-9.

(22) Liteplo, R; Gomes, R.; Howe, P.; Malcolm, H. FluoridesEnvironmental Health Criteria 227, http://www.inchem.org/ documents/ehc/ehc/ehc227.htm (accessed Sep 7, 2016).

(23) Cametti, M.; Rissanen, K. Chem. Commun. 2009, 2809-2829.
(24) Camiolo, S.; Gale, P. A.; Hursthouse, M. B.; Light, M. E.; Shi, A. J. Chem. Commun. 2002, 3, 758-759.

(25) Gale, P. A.; Navakhun, K.; Camiolo, S.; Light, M. E.; Hursthouse, M. B. J. Am. Chem. Soc. 2002, 124, 11228-11229.

(26) Camiolo, S.; Gale, P. A.; Hursthouse, M. B.; Light, M. E. Org. Biomol. Chem. 2003, 1, 741-744.

(27) Gunnlaugsson, T.; Kruger, P. E.; Jensen, P.; Pfeffer, F. M.; Hussey, G. M. Tetrahedron Lett. 2003, 44, 8909-8913.

(28) Esteban-Gómez, D.; Fabbrizzi, L.; Licchelli, M. J. Org. Chem. 2005, 70, 5717-5720.

(29) Evans, L. S.; Gale, P. A.; Light, M. E.; Quesada, R. Chem. Commun. 2006, 965-967.

(30) Pandurangan, K.; Kitchen, J. A.; Gunnlaugsson, T. Tetrahedron Lett. 2013, 54, 2770-2775.

(31) Chiu, C. W.; Gabbaï, F. P. J. Am. Chem. Soc. 2006, 128, 1424814249.

(32) Lee, M. H.; Agou, T.; Kobayashi, J.; Kawashima, T.; Gabbaï, F. P. Chem. Commun. 2007, 1133-1135.

(33) Kim, Y.; Gabbai, F. P. J. Am. Chem. Soc. 2009, 131, 3363-3369.

(34) Perdikaki, K.; Tsagkatakis, I.; Chaniotakis, N. A.; Altmann, R.; Jurkschat, K.; Reeske, G. Anal. Chim. Acta 2002, 467, 197-204.

(35) Yamamoto, H.; Ori, A.; Ueda, K.; Dusemund, C.; Shinkai, S. Chem. Commun. 1996, 407-408.

(36) Dusemund, C.; Sandanayake, S.; Shinkai, S. J. Chem. Soc., Chem. Commun. 1995, 333-334.

(37) Cooper, C. R.; Spencer, N.; James, T. D. Chem. Commun. 1998, $1365-1366$

(38) Sessler, J. L.; Ford, D. A.; Cyr, M. J.; Furuta, H. J. Chem. Soc., Chem. Commun. 1991, 1733-1735.

(39) Chapman, B. E.; Kuchel, P. W. Eur. Biophys. J. 1990, 19, 41-45.

(40) Gorteau, V.; Bollot, G.; Mareda, J.; Matile, S. Org. Biomol. Chem.

2007, 5, 3000-3012.

(41) Berezin, S. K. J. Membr. Biol. 2014, 247, 651-665.

(42) Baker, J. L.; Sudarsan, N.; Weinberg, Z.; Roth, A.; Stockbridge,

R. B.; Breaker, R. R. Science 2012, 335, 233-235.

(43) Lim, H.-H.; Stockbridge, R. B.; Miller, C. Nat. Chem. Biol. 2013, 9, 721-725.

(44) Brammer, A. E.; Stockbridge, R. B.; Miller, C. J. Gen. Physiol. 2014, 144, 129-136.

(45) Stockbridge, R. B.; Robertson, J. L.; Kolmakova-Partensky, L.; Miller, C. eLife 2013, 2, e01084.

(46) Stockbridge, R. B.; Koide, A.; Miller, C.; Koide, S. Nat. Commun. 2014, 5, 5120.

(47) Ji, C.; Stockbridge, R. B.; Miller, C. J. Gen. Physiol. 2014, 144, $257-261$.

(48) Stockbridge, R. B.; Kolmakova-Partensky, L.; Shane, T.; Koide, A.; Koide, S.; Miller, C.; Newstead, S. Nature 2015, 525, 548-551.

(49) Yano, M.; Tong, C. C.; Light, M. E.; Schmidtchen, F. P.; Gale, P. A. Org. Biomol. Chem. 2010, 8, 4356-4363.

(50) Wu, X.; Gale, P. A. J. Am. Chem. Soc. 2016, DOI: 10.1021/ jacs.6b10615.

(51) Wu, X.; Judd, L. W.; Howe, E. N. W.; Withecombe, A. M.; SotoCerrato, V.; Li, H.; Busschaert, N.; Valkenier, H.; Pérez-Tomás, R.; Sheppard, D. N.; Jiang, Y.-B.; Davis, A. P.; Gale, P. A. Chem. 2016, 1, 127-146.

(52) Bindfit www.supramolecular.org (accessed Jun 20, 2016).

(53) Thordarson, P. Chem. Soc. Rev. 2011, 40, 1305-1323.

(54) Sessler, J. L.; Gross, D. E.; Cho, W. S.; Lynch, V. M.; Schmidtchen, F. P.; Bates, G. W.; Light, M. E.; Gale, P. A. J. Am. Chem. Soc. 2006, 128, 12281-12288.

(55) Custelcean, R.; Delmau, L. H.; Moyer, B. A.; Sessler, J. L.; Cho, W. S.; Gross, D.; Bates, G. W.; Brooks, S. J.; Light, M. E.; Gale, P. A. Angew. Chem., Int. Ed. 2005, 44, 2537-2542.

(56) Gale, P. A.; Sessler, J. L.; Kral, V.; Lynch, V. J. Am. Chem. Soc. 1996, 118, 5140-5141.

(57) Fisher, M. G.; Gale, P. A.; Hiscock, J. R.; Hursthouse, M. B.; Light, M. E.; Schmidtchen, F. P.; Tong, C. C. Chem. Commun. 2009, 3017-3019.

(58) Hill, A. V. Biochem. J. 1913, 7, 471-480. 
(59) Brunaldi, K.; Miranda, M. A.; Abdulkader, F.; Curi, R.; Procopio, J. J. Lipid Res. 2005, 46, 245-251.

(60) Kamp, F.; Hamilton, J. A. Proc. Natl. Acad. Sci. U. S. A. 1992, 89, 11367-11370.

(61) Pressman, B. C. Annu. Rev. Biochem. 1976, 45, 501-530.

(62) Mollenhauer, H. H.; James Morre, D.; Rowe, L. D. Biochim. Biophys. Acta, Rev. Biomembr. 1990, 1031, 225-246.

(63) Single-point screenings with the addition of gramicidin and oleic acid together were performed, and the results can be found in the Supporting Information. Minimal differences were shown between these single-point assays and the points with just gramicidin. 